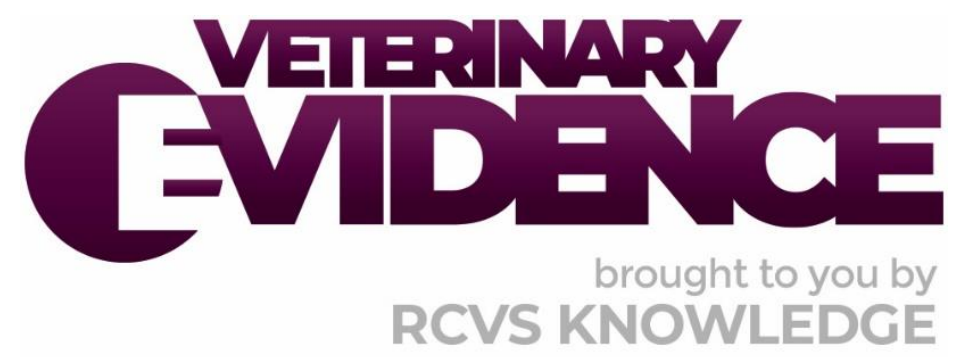

\title{
Can lodine-restricted Diets Normalise Serum Total Thyroxine (TT4) and Subsequently Improve Clinical Signs in Cats With Hyperthyroidism?
}

\author{
A Knowledge Summary by
}

Oliver Gilman BVSc MRCVS ${ }^{*}$

\footnotetext{
${ }^{1}$ University of Bristol, Langford Vets, Langford, Somerset, BS40 5DU United Kingdom

* Corresponding Author (o.gilman.mrcvs@gmail.com)
}

ISSN: 2396-9776

Published: 19 Feb 2019

in: Vol 4, Issue 1

DOI: http://dx.doi.org/10.18849/ve.v4i1.176

Reviewed by: Nicola Ackerman (BSc(Hons) RVN CertSAN

CertVNECC VTS(Nutr) A1 V1 MBVNA) and Sarah

Caney (BVSc PhD DSAM(Feline) MRCVS)

Next Review Date: 19 Feb 2021 


\section{KNOWLEDGE SUMMARY}

\section{PICO question}

In cats with hyperthyroidism, does an iodine-restricted diet normalise the serum TT4 (total thyroxine) levels and reduce the severity of the clinical signs when compared to cats on a normal diet?

\section{Clinical bottom line}

Whilst there is some evidence that iodine-restricted diets can help to renormalise serum TT4 in cats with hyperthyroidism, this is not always effective and there is a lack of compelling evidence to suggest this is associated with a resolution of clinical signs in the long-term.

\section{Clinical Scenario}

Often, a diagnosis of feline hyperthyroidism raises more questions than it solves; with owners striving for a noninvasive and simple treatment for their usually geriatric cat. For the clinician, this has traditionally involved a choice between surgery, lifelong medical management or radioactive iodine treatment. Surgery is invasive, irreversible and carries the risks of anaesthetising a geriatric patient with a strong possibility of concurrent disease. Whereas traditional medical management is lacking in options, often resulting in owners being left with the task of daily/twice-daily tableting of a potentially noncompliant cat. This is often difficult for owners to achieve, and radioactive iodine treatment is only available at limited centres, with owners being required to leave their beloved pet for long periods. What if something as simple as a dietary change could help manage the disease?

\section{Summary of the evidence}

\begin{tabular}{|c|c|}
\hline Hui et al., (2015) & \\
\hline Population: & Client-owned cats with hyperthyroidism \\
\hline Sample size: & 49 \\
\hline Intervention details: & $\begin{array}{l}\text { Cats with hyperthyroidism were fed solely on an iodine-restricted } \\
\text { diet. }\end{array}$ \\
\hline Study design: & Retrospective case series \\
\hline Outcome studied: & $\begin{array}{l}\text { Objective assessment of: } \\
\text { - Heart Rate } \\
\text { - Serum TT4 } \\
\text { - } \text { Blood Urea Nitrogen (BUN) } \\
\text { - Creatinine } \\
\text { Subjective assessment of: } \\
\text { - Weight - Body Condition Score (BCS) }\end{array}$ \\
\hline $\begin{array}{l}\text { Main findings: } \\
\text { (relevant to PICO question): }\end{array}$ & $\begin{array}{l}\text { - Serum TT4 was normalised in } 83 \% \text { of cats by } 180 \text { days. } \\
\text { - Normalisation of TT4 did not lead to any improvement of }\end{array}$ \\
\hline
\end{tabular}




\begin{tabular}{|c|c|}
\hline & $\begin{array}{l}\text { weight or heart rate. } \\
\text { However, weights did stabilise and clinical signs did not } \\
\text { worsen. }\end{array}$ \\
\hline Limitations: & $\begin{array}{l}\text { - Retrospective case studies are relatively low down the } \\
\text { - } \text { Muldence hierarchy. } \\
\text { - Serum TT4 and physical parameters were monitored only for } \\
\text { - } \quad \text { limited time period of } 8 \text { weeks. } \\
\text { - Nine cats had already been treated using methimazole. }\end{array}$ \\
\hline
\end{tabular}

\begin{tabular}{|c|c|}
\hline \multicolumn{2}{|l|}{ van der Kooij et al., (2014) } \\
\hline Population: & $\begin{array}{l}\text { Group 1: Hyperthyroid cats previously medicated with antithyroid } \\
\text { medications. } \\
\text { Group 2: Recently diagnosed and untreated hyperthyroid cats. }\end{array}$ \\
\hline Sample size: & 225 \\
\hline Intervention details: & Hyperthyroid cats were fed solely on an iodine-restricted diet. \\
\hline Study design: & Prospective, multi-centre study. \\
\hline Outcome studied: & $\begin{array}{l}\text { Subjective assessment: } \\
\text { - } \quad \text { Body condition score (1-5) } \\
\text { - } \quad \text { Clinical signs were scored by owners and vets at day 0, week } \\
\quad 4 \text { and week } 8 . \\
\text { Objective assessment: } \\
\text { - TT4 } \\
\text { - Urea } \\
\text { - Creatinine }\end{array}$ \\
\hline $\begin{array}{l}\text { Main findings: } \\
\text { (relevant to PICO question): }\end{array}$ & $\begin{array}{l}\text { - Serum TT4 was normalised in } 75 \% \text { of cats by } 56 \text { days. } \\
\text { - In the remaining } 25 \% \text {, serum } \Pi 44 \text { was lower but still above } \\
\text { the reference range. } \\
\text { - Clinical signs were perceived to have improved by both the } \\
\text { owners and veterinarians. } \\
\text { - BCS stabilised during the course of the study. }\end{array}$ \\
\hline Limitations: & $\begin{array}{l}\text { Weight was monitored with subjective body condition } \\
\text { scores, rather than using scales, and by multiple different } \\
\text { assessors. } \\
\text { - Multiple laboratories were used, with different reference } \\
\text { ranges. } \\
\text { - Missing data due to voluntary participants. } \\
\text { - Not documented if wet or dry food was used - the two } \\
\text { contain differing levels of iodine. }\end{array}$ \\
\hline
\end{tabular}

Fritsch et al., (2014)

Population: $\quad$ Client-owned cats over 10-years-old, with suspected hyperthyroidism and with a serum TT4 $>4.0 \mathrm{ug} / \mathrm{dL}$

Sample size: 22 cats completed the study.

Intervention details: 12 cats were fed a prototype restricted iodine diet and ten were fed a control diet. 


\begin{tabular}{|c|c|}
\hline Study design: & Randomised control trial. \\
\hline Outcome studied: & $\begin{array}{l}\text { Cats were assessed at } 0,3,6 \text { and } 12 \text { weeks. } \\
\text { Subjective assessment: } \\
\text { - Physical examination } \\
\text { Objective assessment: } \\
\text { - Urine specific gravity } \\
\text { - TT4, FT4 and T3 } \\
\text { - BUN } \\
\text { - Creatinine } \\
\text { - Alkaline phosphatase (ALP), alanine transaminase (ALT) and } \\
\text { aspartate aminotransferase (AST) }\end{array}$ \\
\hline $\begin{array}{l}\text { Main findings: } \\
\text { (relevant to PICO question): }\end{array}$ & $\begin{array}{l}\text { - All cats fed the iodine-restricted diet had decreased TT4 } \\
\text { concentrations by the end of the study, with half attaining } \\
\text { euthyroid status. } \\
\text { - In the control group, TT4 was increased in four cats, was } \\
\text { reduced in four cats and stable in two. } \\
\text { - No cats in the control group achieved euthyroid status. } \\
\text { - Serum creatinine, BUN, AST, ALT and urine specific gravity } \\
\text { (USG) remained stable or decreased in cats fed the iodine- } \\
\text { restricted diet. }\end{array}$ \\
\hline Limitations: & $\begin{array}{l}\text { - Funded and designed by Hill's Pet Nutrition, producer of the } \\
\text { iodine-restricted diet. } \\
\text { - Relatively small sample sizes. } \\
\text { - Whether or not there was a resolution of clinical signs was } \\
\text { not mentioned in the discussion. }\end{array}$ \\
\hline
\end{tabular}

\begin{tabular}{|c|c|}
\hline \multicolumn{2}{|l|}{ Vaske et al., (2016) } \\
\hline Population: & Client-owned cats with hyperthyroidism. \\
\hline Sample size: & 15 \\
\hline Intervention details: & $\begin{array}{l}\text { Cats were fed an iodine-restricted diet (Hills } y / d \text {, the proprietary diet } \\
\text { produced by Hill's Pet Nutrition) dry or canned version) and assessed } \\
\text { at } 0,1,2,3 \text { \& } 6 \text { months }\end{array}$ \\
\hline Study design: & Prospective study \\
\hline Outcome studied: & $\begin{array}{l}\text { Subjective: } \\
\text { - Physical examination } \\
\text { Objective: } \\
\text { - TT4 } \\
\text { - Haematology } \\
\text { - Biochemistry } \\
\text { - Symmetric dimethylarginine assay (SDMA) } \\
\text { - Urinalysis, urine protein to creatinine ratio (UPC), gamma- } \\
\text { - glutamyl transferase (GGT) and creatinine }\end{array}$ \\
\hline $\begin{array}{l}\text { Main findings: } \\
\text { (relevant to PICO question): }\end{array}$ & $\begin{array}{l}\text { - TT4 was reduced in } 100 \% \text { of the cats after } 6 \text { months. } \\
\text { - } \quad 9-10 \text { cats remained persistently hyperthyroid after } 6\end{array}$ \\
\hline
\end{tabular}




\begin{tabular}{|l|l|}
\hline & months. \\
\hline Limitations: & $\begin{array}{l}\text { - } \\
\end{array}$ \\
& $\begin{array}{l}\text { ionded and designed by Hill's Pet Nutrition, producer of the } \\
\text { - Very small sample size. }\end{array}$ \\
& $\begin{array}{l}\text { - Whether or not there was a resolution of clinical signs was } \\
\text { not mentioned in the discussion. }\end{array}$ \\
\hline
\end{tabular}

\begin{tabular}{|c|c|}
\hline \multicolumn{2}{|l|}{ Scott-Moncrieff (2015) } \\
\hline Population: & Client-owned hyperthyroid cats. \\
\hline Sample size: & 8 \\
\hline Intervention details: & Cats were fed an iodine-restricted diet for 6 months. \\
\hline Study design: & Prospective study \\
\hline Outcome studied: & $\begin{array}{l}\text { Subjective: } \\
\text { - Physical examination } \\
\text { Objective: } \\
\text { - TT4 } \\
\text { - } \mathrm{fT} 4 \\
\text { - Haematology } \\
\text { - Biochemistry } \\
\text { - Urinalysis } \\
\text { - }{ }^{123} \text { (a radioactive lodine isotope) uptake by thyroid glands } \\
\text { scintigraphically }\end{array}$ \\
\hline $\begin{array}{l}\text { Main findings: } \\
\text { (relevant to PICO question): }\end{array}$ & $\begin{array}{l}\text { - Clinical signs reportedly resolved. } \\
\text { - Both } T 44 \text { and fT4 were significantly improved, with } 7 / 8 \text { cats } \\
\text { achieving euthyroid status by week } 8 \text {. } \\
\text { - No significant change in body weight. }\end{array}$ \\
\hline Limitations: & $\begin{array}{l}\text { Very small sample size. } \\
\text { - Whilst it is stated that clinical signs resolved, there is no } \\
\text { standardised assessment described. }\end{array}$ \\
\hline
\end{tabular}

\section{Appraisal, application and reflection}

During the literature search, it soon became apparent that there were only limited studies investigating the efficacy of the relatively recently introduced iodine-restricted diets for successful control of feline hyperthyroidism. A second point of note was that a substantial proportion of the studies into iodinerestricted diets were undertaken in conjunction with Hill's Pet Nutrition, a key developer and producer of the commercially available diet, and unfortunately this introduces a suspicion of potential bias in those studies.

Both the papers from van der Kooij et al., (2014) and Hui et al., (2015) used a large sample population, but unfortunately the studies by Fritsch et al., (2014), Scott-Moncrieff et al., (2015) and Vaske et al., (2016) had more limited sample sizes of 22,8 and 15 respectively, reducing the reliability of their findings.

A limitation of all the studies into this subject is the difficulty in maintaining and proving $100 \%$ compliance, as all the patients enrolled in the studies were client-owned and potentially allowed outdoor access. As well as this, documenting an improvement in clinical signs is difficult, given the subjective nature of the task, and made more complicated by the fact that the cats were only assessed by veterinarians at set intervals (it is also unclear whether or not these assessments were made by the same veterinarian). van der Kooij et al., (2014) used an online questionnaire, allowing owners to submit data regarding the clinical signs, however 
details of the questionnaire are not included in the paper, so its suitability cannot be assessed. Finally, the limited follow-up undertaken during any of the studies reduces the value of any conclusions that can be made.

Hui et al., (2015) included nine cats which had already been taking methimazole as treatment, prior to starting the iodine-restricted diet. Whilst it was ensured methimazole treatment had been halted, and TT4 was over the reference range before starting the iodine-restricted diet and including these cats in the study, there was no information regarding how long the methimazole had been stopped for, or whether TT4 had returned to pre-methimazole treatment levels.

All of the studies found that by the end of their follow-up period $100 \%$ of the cats had lower serum TT4 values than when they were started on the iodine restricted diet. Hui et al., (2015) found that by 61-180 days into treatment serum TT4 had normalised in $83 \%$ of the cats in the study. van der Kooij et al., (2014) had similar findings, with $75 \%$ of those cats having normal serum TT4 by week 8 . Similarly, Scott-Moncrieff et al., (2015) found serum TT4 normalised in seven out of eight cats by week 8. Fritsch et al., (2014) reported 50\% of the enrolled cats becoming euthyroid by week 12 and Vaske et al., (2016) had 33\% of the cats become euthyroid by 6 months into treatment.

Neither of the studies by Fritsch et al., (2014) or Vaske et al., (2016) monitored clinical signs during the iodine-restricted diet trial, so it is impossible to draw any conclusions regarding improvement of clinical signs from these studies. Hui et al., (2015) documented a cessation of the progression of clinical signs, whilst both Scott-Moncrieff et al., (2015) and van der Kooij et al., (2014) showed an improvement, perceived by both owners and veterinarians.

No cats were removed from any of the studies due to concerns about the safety of the diet, or as a result of any side effects, so it can be concluded at least that the diet is safe.

So whilst there is limited literature investigating the efficacy of iodine-restricted diets as a treatment for feline hyperthyroidism, all the studies so far have documented a $100 \%$ improvement in serum TT4 when cats have been started on an iodine restricted diet, though this did not always guarantee a return to euthyroid status. There is, however, a lack of consensus regarding the resolution of clinical signs. Further to this disparity amongst the literature, the limited number of studies and the limitations of those studies mean a prospective study with large sample size and- lifelong follow-up would improve the evidence base greatly.

\section{Methodology Section}

\begin{tabular}{|c|c|}
\hline \\
\hline $\begin{array}{r}\text { Databases searched and dates } \\
\text { covered: }\end{array}$ & $\begin{array}{l}\text { OVID Medline on OVID SP } 1946 \text { - Week } 42019 \\
\text { Web of Science Core Collection on Web of Science } 1946 \text { - Week } 4 \\
2019 \\
\text { OVID CAB Abstracts } 1973 \text { - Week } 42019\end{array}$ \\
\hline Search terms: & $\begin{array}{l}\text { ‘Animal Feed’ OR ‘Diet’ AND ‘Cats' OR ‘Feline' AND } \\
\text { 'Hyperthyroidism' }\end{array}$ \\
\hline Dates searches performed: & $22 / 01 / 19$ \\
\hline
\end{tabular}

\section{Exclusion / Inclusion Criteria}

Exclusion: Articles not in English, unrelated to the PICO, single case reports, book chapters and conference proceedings.

Inclusion: Articles in English, related to the PICO. 


\begin{tabular}{|l|c|c|c|c|c|}
\hline \multicolumn{1}{|c|}{ Search Outcome } & \multicolumn{2}{|c|}{ Total } \\
\hline \multicolumn{1}{|c|}{ Database } & $\begin{array}{c}\text { Number of } \\
\text { results }\end{array}$ & $\begin{array}{c}\text { Excluded - } \\
\text { Relevance }\end{array}$ & $\begin{array}{c}\text { Excluded - } \\
\text { Language }\end{array}$ & $\begin{array}{c}\text { Excluded - } \\
\text { Duplicates }\end{array}$ & $\begin{array}{c}\text { Tolevant } \\
\text { papers }\end{array}$ \\
\hline Ovid Medline & 228 & 225 & 0 & 0 & 3 \\
\hline CAB Abstracts & 485 & 480 & 0 & 3 & 2 \\
\hline Web of Science & 24 & 19 & 0 & 5 & 5 \\
\hline
\end{tabular}

\section{CONFLICT OF INTEREST}

The author declares no conflicts of interest.

\section{REFERENCES}

1. Fritsch, D., Allen, T., Dodd, C., Wedekind, K. \& Sixby, K. 2014. A Restricted lodine Food Reduces Circulating Thyroxine Concentrations in Cats with Hyperthyroidism. International Journal of Applied Research in Veterinary Medicine, 12(1), pp.24-32.

2. Hui, T., Bruyette, D., Moore, G. \& Scott-Moncrieff, J. 2015. Effect of Feeding an lodine-Restricted Diet in Cats with Spontaneous Hyperthyroidism. Journal of Veterinary Internal Medicine, 29(4), pp.10631068. http://dx.doi.org/10.1111/jvim.13368

3. van der Kooij, M., Becvarova, I., Meyer, H., Teske, E. \& Kooistra, H. 2014. Effects of an iodine-restricted food on client-owned cats with hyperthyroidism. Journal of Feline Medicine and Surgery, 16(6), pp.491-498. http://dx.doi.org/10.1177/1098612X13512627

4. Vaske, H., Armbrust, L., Zicker, S., Jewell, D. \& Grauer, G. 2016. Assessment of Renal Function in Hyperthyroid Cats Managed with a Controlled lodine Diet. International Journal of Applied Research in Veterinary Medicine, 14(1), pp.38-48.

5. Scott-Moncrieff, J., Heng, H., Weng, H., Diemo, D. \& Jones, M. 2015. Effect of a Limited lodine Diet on lodine Uptake by Thyroid Glands in Hyperthyroid Cats. Journal of Veterinary Internal Medicine, 29, pp.1322-1326. http://dx.doi.org/10.1111/ivim.13577 


\section{EVIIDEFeE

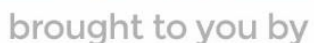 \\ RCVS KNOWLEDGE}

\section{Intellectual Property Rights}

Authors of Knowledge Summaries submitted to RCVS Knowledge for publication will retain copyright in their work, and will be required to grant RCVS Knowledge a non-exclusive license of the rights of copyright in the materials including but not limited to the right to publish, re-

publish, transmit, sell, distribute and otherwise use the materials in all languages and all media throughout the world, and to license or permit others to do so.

\section{Disclaimer}

Knowledge Summaries are a peer-reviewed article type which aims to answer a clinical question based on the best available current evidence. It does not override the responsibility

of the practitioner. Informed decisions should be made by considering such factors as individual clinical expertise and judgement along with patient's circumstances and owners' values. Knowledge Summaries are a resource to help inform and any opinions expressed within the Knowledge Summaries are the author's own and do not necessarily reflect the view of the RCVS Knowledge. Authors are responsible for the accuracy of the content. While the

Editor and Publisher believe that all content herein are in accord with current recommendations and practice at the time of publication, they accept no legal responsibility

for any errors or omissions, and make no warranty, express or implied, with respect to material contained within.

For further information please refer to our Terms of Use.

RCVS Knowledge is the independent charity associated with the Royal College of Veterinary Surgeons (RCVS). Our ambition is to become a global intermediary for evidence based veterinary knowledge by providing access to information

that is of immediate value to practicing veterinary professionals and directly contributes to evidence based clinical decision-making.

\section{https://www.veterinaryevidence.org/}

RCVS Knowledge is a registered Charity No. 230886.

Registered as a Company limited by guarantee in England and Wales No. 598443.

Registered Office: Belgravia House, 62-64 Horseferry Road, London SW1P 2AF

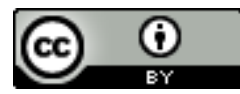

This work is licensed under a Creative Commons Attribution 4.0 International License. 